\title{
IMPROVING THE COMPARABILITY OF BRIEF-COPE RESULTS THROUGH EXAMINATION OF SECOND-ORDER STRUCTURES: A STUDY WITH SPANISH ADOLESCENTS
}

\author{
Cristina Serrano1, Yolanda Andreu¹, Paula Martínez² \\ and Sergio Murgui ${ }^{1}$ \\ ${ }^{1}$ University of Valencia; ${ }^{2}$ Valencian International University (Spain)
}

\begin{abstract}
The Brief-Coping Orientation to Problems Experienced (Brief-COPE) is a widely used instrument, although with limitations regarding reliability and factorial structure. This study with 611 adolescents examines the Brief-COPE's internal structure, reliability, and convergent validity. Structures tested through confirmatory factor analysis were the original 14 subscales, as well as three secondorder structures derived from previous COPE research and from Connor-Smith and Flachsbart's proposal. All the structures examined obtained a good fit. However, internal consistency and convergent validity findings only supported the use of a model in which religion and self-blame constitute independent subscales while the remaining subscales shaped three second-order factors: self-sufficient, socially supported, and disengagement coping. This hierarchical structure reflects a model emphasized by research with adolescents, makes the use of this instrument valuable, and does not prevent the exploration of original subscales with appropriate reliability levels. Consequently, our results constitute a significant step forward in the improvement of the usefulness and comparability of the coping results obtained with the Brief-COPE.

KEY WORDS: coping, Brief-COPE, adolescents, factor structure.
\end{abstract}

\section{Resumen}

El "Inventario breve de afrontamiento de los problemas experimentados" (COPE-breve) es un instrumento ampliamente utilizado, aunque con limitaciones respecto a su fiabilidad y estructura factorial. Este estudio con 611 adolescentes examina la estructura interna, fiabilidad y validez convergente del COPE-Breve. Las estructuras evaluadas mediante análisis factorial confirmatorio fueron las 14 subescalas originales y tres estructuras de segundo orden derivadas de los resultados previos del COPE y de la propuesta de Connor-Smith y Flachsbart. Todas las estructuras obtuvieron un buen ajuste. Sin embargo, los resultados de consistencia interna y validez convergente respaldaron un único modelo en el que religión y culpa se mantuvieron como subescalas independientes y el resto formaron tres factores de segundo orden: afrontamiento pasivo, autosuficiente y socialmente apoyado. Esta estructura jerárquica refleja el modelo enfatizado por la

Correspondence: Yolanda Andreu, University of Valencia, Av. Blasco Ibáñez, 21, 46010 Valencia (Spain). E-mail: yolanda.andreu@uv.es 
investigación con adolescentes, rentabiliza el uso del instrumento y permite explorar las subescalas originales que presenten niveles apropiados de fiabilidad. Así, nuestros resultados constituyen un paso significativo para mejorar la utilidad y comparabilidad de los resultados obtenidos con el COPE-breve.

PALABRAS CLAVE: afrontamiento, COPE-breve, adolescentes, estructura factorial.

\section{Introduction}

Coping is conceptualized since the Lazarus and Folkman's transactional model (1984) as the cognitive and behavioural efforts that people use to manage specific external and/or internal demands that are appraised as taxing or exceeding their resources. To study the coping processes, the authors developed one of the most widely used instruments, the Ways of Coping inventory (WOC; Folkman \& Lazarus, $1980,1985)$. Embedded in the scale is a distinction between two general types of coping, depending on whether it is directed to remove/evade the source of stress itself (problem-focused coping) or to reduce/handle thoughts and feelings associated with the stressor (emotion-focused coping). However, the subsequent research results showed diverse factorial structures which include from two to eight factors (Aliaga \& Capafons, 1996).

Carver, Scheier, and Weintraub (1989) considered previous results indicative of the need for greater differentiation in addressing the diversity of potential coping responses than that captured by problem- and emotion-focused coping. To assess a broader variety of coping styles, authors developed the Coping Orientation to Problems Experienced (COPE) inventory, a 60-item self-report measure with initially thirteen scales or ways in which people respond to stressors. As a result of the factor analysis, four factors were obtained (problem-focused coping, emotion-focused coping, socially supported, and disengagement coping) and religion subscale failed to load substantially in any of these. After initial research, two subscales (humor and substance use) were added, so fifteen coping strategies were finally evaluated (Carver et al., 1989). The COPE has been widely used and adapted to several languages, such as Spanish (Crespo \& Cruzado, 1997), Romanian (Crasovan \& Sava, 2013), Italian (Sica, Novara, Dorz, \& Sanavio, 1997), and Estonian (Kallasmaa \& Pulver, 2000). Results from other studies yielded similar factor structures, with religion subscale failing again to group on either of the factors, but humor subscale predominantly loads on the emotion-focused coping, and substance use subscale on disengagement coping (e.g., Litman, 2006; Lyne \& Roger, 2000) (Appendix). Moreover, the emotion- and problem-focused scales often loads on the same factor (e.g., Cassaretto \& Pérez-Araníbar, 2016).

To reduce time burden and facilitate administration, authors refined the original scale resulting in a shortened version (Brief-COPE; Carver, 1997) that consists of 28 items grouped in fourteen two-item subscales: self-distraction, active coping, denial, substance use, use of emotional support, use of instrumental support, behavioural disengagement, venting, positive reframing, planning, humor, acceptance, religion, and self-blame. In this abbreviated form, two COPE subscales - restraint coping and suppression of competing activities- were eliminated for their 
limited usefulness; three others -positive reinterpretation and growth, focus on \& venting of emotions and mental disengagement- were slightly modified to sharpen their focus, and, finally, self-blame was added as a new subscale (Carver, 1997) (Appendix). The initial study showed limitations regarding the reliability and internal structure of the Brief-COPE: three of the subscales (venting, denial, and acceptance) didn't meet the minimum value of .60, and there were nine factors resulting from factor analysis (only substance use, religion, humor, and behavioral disengagement accounted for a single factor) (Carver, 1997). Despite the above, the Brief-COPE has been one of the most widely used instrument for assess coping, and it has been analysed and adapted to various languages such as Brazilian-Portuguese (Brasileiro et al., 2016), French (Muller \& Spitz, 2003), Spanish (Morán, Landero, \& González, 2010), and Tamil (Mohanraj et al., 2015). However, problems persist with regard to poor internal consistency of some subscales (Carver 1997; Doron, Stephan, Boiché, \& Le Scanff, 2009; Kristiansen, Roberts, \& Abrahamsen, 2008). Thus, in order to achieve higher internal consistency indices and based on Carver's suggestion (1997) to flexible use and grouping of subscales according to specific research, several studies include factor analyses on their own datasets that allow to group different subscales (e.g., Baumstarck et al., 2017; Brasileiro et al., 2016; Mate, Andreu, \& Peña, 2016). As a result, there has also been a proliferation of 'ad hoc' factor structures not always guided by a theoretical or aprioristic approach (e.g., Baumstarck et al., 2017; Brasileiro et al., 2016; Doron et al., 2014; Mate et al., 2016). From the above, it would seem reasonable to explore possible second-order Brief-COPE structures that enable a consensual use of the scale and the comparison of results in different samples. In this regard and considering the results from the COPE (Litman, 2006), it is possible to propose two higher order structures: a fourfactor structure with problem-focused, emotion-focused, disengagement (avoidant), and socially supported coping (Appendix), and a three-factor structure in which problem- and emotion-focused coping would be grouped into a single factor called self-sufficient coping. In both cases, religion and self-blame subscales would form separate factors because of the complexity of constructs themselves. Selfblame has been conceptualized as a coping strategy which refers to a passive and repetitive focus on the negative and damaging characteristics of a stressful transaction (Skinner, Edge, Altman, \& Sherwood, 2003). It has also been defined as an involuntary engagement stress reaction (Connor-Smith, Compas, Wadsworth, Thomsen, \& Saltzman, 2000), and even as a causal attribution (Janoff-Bulman, 1979). On the other hand, it is possible to identify different modalities of religious coping that cover a broad spectrum of response types: active, passive, and interactive activities; problem-focused; and emotion-focused. In fact, the use of general or unidimensional religious coping measures to inform about the role of religion in dealing with stress has been criticized (Lavery \& O'Hea, 2010; Schottenbauer et al., 2006). Finally, a precision is needed concerning the selfdistraction coping strategy. Although historically it has been considered disengagement coping, confirmatory factorial analyses (CFA) consistently indicate that intentionally engaging in positive activities is an engagement strategy used to adapt to uncontrollable events (Carver \& Connor-Smith, 2010; Skinner et al., 2003). Thus, although Appendix reflects the initial proposal arising from COPE, models 
under exploration will consider this strategy as emotion-focused engagement coping.

A different form of grouping the strategies measured by the Brief-COPE could result from the Connor-Smith and Flachsbart (2007) proposal. These authors suggest a hierarchical structure of coping resulting from previous CFA (e.g., Ayers, Sandler, West, \& Roosa, 1996; Connor-Smith et al., 2000; Walker, Smith, Garber, \& Van Slyke, 1997) and which incorporates the most broadly distinctions used to describe the coping structure according to their orientation and goals. At the top of the hierarchy is found the distinction between engagement (approach) and disengagement coping (avoidant). At the next level, engagement coping can be further distinguished into assimilative and accommodative (also, primary and secondary control, respectively) coping. Assimilative coping includes strategies targeted toward changing the stressor or related emotions, while accommodative coping includes strategies that emphasize adaptation to stress (Compas, ConnorSmith, Saltzman, Thomsen, \& Wadsworth, 2001; Skinner et al., 2003). According to this proposal, the subscales of the Brief-COPE could be corresponding as shown in Appendix.

Given the common use of the Brief-COPE and the inconsistency of the results, the aim of the current study was to examine its factor structure in a large sample of Spanish adolescents. Structures tested through CFA were the four previously described: the original 14 first-order factors of the Brief-COPE, the two empirical structures obtained from COPE results with four and three second-order factors, and the proposal by Connor-Smith and Flachsbart (2007). A secondary aim was to analyse the Brief-COPE subscales internal consistency and convergent validity through its relationship with subjective wellbeing and perceived stress.

\section{Method}

\section{Participants}

The total sample was composed of 611 (303 females, 308 males) Spanish adolescents aged 14 to $18(M=15.49$ years, $S D=1.00)$, who were attending to $3^{\text {rd }}$ and $4^{\text {th }}$ year of secondary school $\left(32.9 \%, 40.9 \%\right.$, respectively), or $1^{\text {st }}$ year of A-levels $(26.2 \%)$.

\section{Instruments}

a) Brief Coping Orientation to Problems Experienced (Brief-COPE; Carver, 1997). The Brief-COPE is a self-report measure of coping strategies. The 28-items are rated on a 4-point Likert scale exploring 14 two-items subscales: active coping, planning, use of instrumental support, positive reframing, acceptance, use of emotional support, denial, venting, self-blame, humor, religion, self-distraction, substance use and behavioural disengagement. The inventory provides 14 scores in which a higher value reflects a higher tendency to implement the corresponding coping strategy. The Spanish version of the Brief-COPE has shown adequate psychometric properties (Morán et al., 2010). 
b) Subjective Happiness Scale (SHS; Lyubomirsky \& Lepper, 1999). The SHS is a selfreport questionnaire that assesses subjective wellbeing. It comprises four items whose responses are made on a 7-point Likert scale. The first two items demand participants to describe themselves using both absolute ratings and ratings relative to peers, while the other two items propose brief descriptions of happy and unhappy individuals and respondents are asked to what extent each description fits them. The results obtained show that the Spanish version of the SHS is a reliable and valid measure of subjective wellbeing (Extremera, Fernandez-Berrocal, Gonzalez-Herrero, \& Cabello, 2009). For the present study, total score indicated an adequate internal consistency (Cronbach's $\alpha=.76)$.

c) Perceived Stress Scale (PSS; Cohen, Kamarck, \& Mermelstein, 1983). The PSS measures the degree of stress experienced in the past month using 14 items evaluated on a 5-point Likert scale. The instrument offers a single score in which higher values indicate higher perceived stress. The results obtained from the PSS Spanish version have supported reliability and validity of the instrument (Remor \& Carrobles, 2001). The internal consistency of the scale for this study was satisfactory (Cronbach's $\alpha=.79$ ).

\section{Procedure}

Several secondary schools belonging to the Community of Valencia (Spain) were contacted by email to inform about the study and request their participation. The school boards of the interested centres provided the informed consent. After explaining the aim of the study, the participants also provided it. Then, the questionnaires were fulfilled anonymously, in paper-and-pencil format and in presence of a research.

\section{Data analyses}

All statistical analyses were performed using IBM SPSS Statistics v. 21.0 and EQS 6.0 (Bentler, 2006). Descriptive statistics were calculated to summarize the socio-demographic and psychological characteristics. Four models were tested: Brief-COPE's original 14-factor structure (model A) and three second-order structures which differ in the proposed grouping for the engagement subscales. Two empirical second-order structures emerging from COPE that differ depending on whether emotion-focused coping and problem-focused coping define two distinct factors (model B) or are grouped into a single factor (model C) between assimilative and accommodative coping (model D). All models consider religion and self-blame as independent subscales, classify self-distraction as engagement coping, and group disengagement subscales into a single factor. Different fit indices were used and computed to evaluate the goodness of fit of the models to the data (Jackson, Gillaspy, \& Purc-Stephenson, 2009): root mean square error of approximation (RMSEA), non-normed fit index (NNFI), Bollen incremental fit index (IFI), and comparative fit index (CFI). The Satorra-Bentler chi-squared (S-B $\left.\chi^{2}\right)$ test and S-B $\chi^{2} / d f$ were also considered. We used a robust version of the maximum likelihood estimator (ML), in view of the deviation from normality of the data (Mardia's 
normalized coefficient higher than 3.00). We followed Hair, Anderson, Tatham, and Black (1999) to establish the acceptable cut-off criteria. Furthermore, internal consistency of the Brief-COPE was measured by Cronbach's alphas, and its convergent validity was based on the Pearson's correlation between Brief-COPE, SHS and PSS.

\section{Results}

Descriptive data and factor structure

Descriptive statistics of the Brief-COPE, SHS and PSS are presented in Table 1.

Table 1

Descriptive statistics of the variables

\begin{tabular}{|c|c|c|c|c|}
\hline Variables & $M$ & $S D$ & Range of scores & Cronbach's $\alpha$ \\
\hline \multicolumn{5}{|l|}{ Brief-COPE subscales } \\
\hline Positive reframing & 5.58 & 1.32 & $2-8$ & .57 \\
\hline Humor & 4.75 & 1.69 & $2-8$ & .74 \\
\hline Acceptance & 5.93 & 1.21 & $2-8$ & .49 \\
\hline Self-distraction & 5.42 & 1.18 & $2-8$ & .25 \\
\hline Active coping & 5.98 & 1.03 & $2-8$ & .40 \\
\hline Planning & 5.57 & 1.22 & $2-8$ & .50 \\
\hline Instrumental support & 5.81 & 1.35 & $2-8$ & .67 \\
\hline Emotional support & 5.77 & 1.40 & $2-8$ & .73 \\
\hline Venting & 5.49 & 1.55 & $2-8$ & .56 \\
\hline Denial & 3.84 & 1.41 & $2-8$ & .60 \\
\hline Substance use & 2.65 & 1.22 & $2-8$ & .84 \\
\hline Behavioural disengagement & 3.59 & 1.22 & $2-8$ & .64 \\
\hline Religion & 2.97 & 1.43 & $2-8$ & .76 \\
\hline Self-blame & 5.10 & 1.60 & $2-8$ & .65 \\
\hline \multicolumn{5}{|l|}{ Brief-COPE factors } \\
\hline Self-sufficient & 33.21 & 4.35 & $17-45$ & .67 \\
\hline Emotion-focused & 21.67 & 3.37 & $12-32$ & .60 \\
\hline Problem-focused & 11.54 & 1.82 & $4-16$ & .54 \\
\hline Socially supported & 17.07 & 3.44 & $6-24$ & .78 \\
\hline Disengagement & 10.09 & 2.74 & $6-21$ & .68 \\
\hline Assimilative & 28.61 & 4.21 & $13-40$ & .72 \\
\hline Accommodative & 21.67 & 3.37 & $12-32$ & .60 \\
\hline SHS total score & 20.00 & 4.40 & $5-28$ & .76 \\
\hline PSS total score & 27.24 & 7.18 & $6-50$ & .79 \\
\hline
\end{tabular}

Note: $\mathrm{SHS}=$ Subjective Happiness Scale; PSS= Perceived Stress Scale.

First, we calculated model A (original 14-factor structure) to check the item's saturation in each factor (Table 2). Then, three different structural factor models were computed: model B (problem-focused, emotion-focused, disengagement, and 
socially supported coping), model C (self-sufficient, disengagement and socially supported coping), and model D (Connor-Smith and Flachsbart proposal).

Table 2

Factorial saturations of items for model A

\begin{tabular}{|c|c|c|c|}
\hline Factor/Item & Saturation & Factor/ltem & Saturation \\
\hline \multicolumn{2}{|l|}{ Positive reframing } & \multicolumn{2}{|l|}{ Using emotional support } \\
\hline $\begin{array}{l}\text { 14. I've been trying to see it } \\
\text { in a different light, to } \\
\text { make it seem more } \\
\text { positive }\end{array}$ & .59 & $\begin{array}{l}\text { 9. I've been getting emotional } \\
\text { support from others }\end{array}$ & .67 \\
\hline $\begin{array}{l}\text { 18. I've been looking for } \\
\text { something good in what } \\
\text { is happening }\end{array}$ & .69 & $\begin{array}{l}\text { 17. I've been getting comfort } \\
\text { and understanding from } \\
\text { someone }\end{array}$ & .81 \\
\hline \multicolumn{2}{|l|}{ Humor } & \multicolumn{2}{|l|}{ Venting } \\
\hline $\begin{array}{l}\text { 7. I've been making jokes } \\
\text { about it }\end{array}$ & .81 & $\begin{array}{l}\text { 12. I've been saying things to } \\
\text { let my unpleasant feelings } \\
\text { escape }\end{array}$ & .58 \\
\hline $\begin{array}{l}\text { 19. I've been making fun of } \\
\text { the situation }\end{array}$ & .71 & $\begin{array}{l}\text { 23. I've been expressing my } \\
\text { negative feelings }\end{array}$ & .60 \\
\hline \multicolumn{2}{|l|}{ Acceptance } & \multicolumn{2}{|l|}{ Denial } \\
\hline $\begin{array}{l}\text { 3. I've been accepting the } \\
\text { reality of the fact that it } \\
\text { has happened }\end{array}$ & .79 & $\begin{array}{l}\text { 5. I've been saying to myself } \\
\text { "this isn't real" }\end{array}$ & .62 \\
\hline $\begin{array}{l}\text { 21. I've been learning to live } \\
\text { with it }\end{array}$ & .71 & $\begin{array}{l}\text { 13. I've been refusing to } \\
\text { believe that it has } \\
\text { happened }\end{array}$ & .67 \\
\hline \multicolumn{2}{|l|}{ Self-distraction } & \multicolumn{2}{|l|}{ Substance use } \\
\hline $\begin{array}{l}\text { 4. I've been turning to work } \\
\text { or other activities to take } \\
\text { my mind off things }\end{array}$ & .87 & $\begin{array}{l}\text { 15. I've been using alcohol or } \\
\text { other drugs to make } \\
\text { myself feel better }\end{array}$ & .81 \\
\hline $\begin{array}{l}\text { 22. I've been doing } \\
\text { something to think about } \\
\text { it less, such as going to } \\
\text { movies and watching TV }\end{array}$ & .16 & $\begin{array}{l}\text { 24. I've been using alcohol or } \\
\text { other drugs to help me get } \\
\text { through it }\end{array}$ & .90 \\
\hline \multicolumn{2}{|l|}{ Active coping } & \multicolumn{2}{|l|}{ Behavioral disengagement } \\
\hline $\begin{array}{l}\text { 2. I've been concentrating } \\
\text { my efforts on doing } \\
\text { something about the } \\
\text { situation I'm in }\end{array}$ & .57 & $\begin{array}{l}\text { 11. I've been giving up trying } \\
\text { to deal with it }\end{array}$ & .70 \\
\hline $\begin{array}{l}\text { 10. I've been taking action to } \\
\text { try to make the situation } \\
\text { better }\end{array}$ & .45 & $\begin{array}{l}\text { 25. I've been giving up the } \\
\text { attempt to cope }\end{array}$ & .69 \\
\hline \multicolumn{2}{|l|}{ Planning } & \multicolumn{2}{|l|}{ Religion } \\
\hline $\begin{array}{l}\text { 6. I've been trying to come } \\
\text { up with a strategy about } \\
\text { what to do }\end{array}$ & .55 & $\begin{array}{l}\text { 16. I've been trying to find } \\
\text { comfort in my religion or } \\
\text { spiritual beliefs }\end{array}$ & .61 \\
\hline $\begin{array}{l}\text { 26. I've been thinking hard } \\
\text { about what steps to take }\end{array}$ & .60 & $\begin{array}{l}\text { 20. I've been praying or } \\
\text { meditating }\end{array}$ & .98 \\
\hline
\end{tabular}




\begin{tabular}{|c|c|l|c|}
\hline \multicolumn{1}{|c|}{ Factor/ltem } & Saturation & \multicolumn{1}{|c|}{ Factor/Item } & Saturation \\
\hline Using instrumental support & .63 & Self-blame & .58 \\
\hline $\begin{array}{c}\text { 1. I've been trying to get } \\
\text { advice or help from other } \\
\text { people about what to do }\end{array}$ & .78 & $\begin{array}{r}\text { 27. I've been blaming myself } \\
\text { for things that happened }\end{array}$ & .82 \\
\hline $\begin{array}{l}\text { 28. I've been getting help } \\
\text { and advice from other } \\
\text { people }\end{array}$ & .2 \\
\hline
\end{tabular}

The adequacy of four studied structures is shown in Table 3. The analysis revealed that model $A$ obtained a good fit to the data while the other three higherorder structures obtained satisfactory fit indices after being recalculated including the covariance between items and between factors a few cross-loadings. The improved models B and C were equivalents due to comparable goodness of fit indices, and the improved model $D$ reached a slightly better fit than the two previous models.

Table 3

Model fit indices

\begin{tabular}{|c|c|c|c|c|c|c|c|c|}
\hline Model & S-B $\chi^{2}$ & $d f$ & S-B $\chi^{2} / d f$ & RCFI & IFI & RNNFI & $\begin{array}{c}\text { RMSEA } \\
{[90 \% \mathrm{CI}]}\end{array}$ & AIC \\
\hline Model A & 402.19 & 259 & 1.55 & .95 & .96 & .93 & $\begin{array}{c}.030 \\
{[.024-.036]}\end{array}$ & -115.81 \\
\hline Model B & 753.69 & 328 & 2.30 & .86 & .86 & .84 & $\begin{array}{c}.046 \\
{[.041-.050]}\end{array}$ & 97.79 \\
\hline Model C & 649.40 & 328 & 1.98 & .89 & .90 & .88 & $\begin{array}{c}.040 \\
{[.036-.045]}\end{array}$ & -6.60 \\
\hline Model D & 823.38 & 328 & 2.51 & .84 & .84 & .81 & $\begin{array}{c}.050 \\
{[.046-.054]}\end{array}$ & 167.38 \\
\hline $\begin{array}{l}\text { Model B } \\
\text { improved }\end{array}$ & 394.31 & 312 & 1.26 & .97 & .97 & .97 & $\begin{array}{c}.021 \\
{[.014-.027]}\end{array}$ & -229.69 \\
\hline $\begin{array}{l}\text { Model C } \\
\text { improved }\end{array}$ & 423.49 & 314 & 1.35 & .96 & .97 & .96 & $\begin{array}{c}.024 \\
{[.018-.030]}\end{array}$ & -204.50 \\
\hline $\begin{array}{l}\text { Model D } \\
\text { improved }\end{array}$ & 436.68 & 314 & 1.39 & .96 & .96 & .95 & $\begin{array}{c}.025 \\
{[.019-.031]}\end{array}$ & -191.32 \\
\hline
\end{tabular}

Note: $\mathrm{S}-\mathrm{B} \chi^{2}=$ Satorra-Bentler chi-squared; $\mathrm{RCFl}=$ robust comparative fit index; $\mid \mathrm{FI}=$ incremental fit index; $\mathrm{RNNFI}=$ robust non-normed fit index; RMSEA = root mean square error of approximation; $\mathrm{AIC}=\mathrm{Akaike}$ information criterion.

\section{Reliability Brief-COPE factors}

Cronbach's alphas for the original 14 Brief-COPE scales (model A) are reported in Table 1. The values ranged from .25 to .84 : six scales obtained poor reliability with values that not even reach the .60 , two of them (self-distraction and active coping) with values $\leq .40$. Except for problem-focused coping $(\alpha=.54)$, Cronbach's alphas values for all other second-order factors considered in the hierarchical models $(B, C$, and D) were acceptable with a range from .60 to .78 (see Table 1). Consequently, 
model B which included the problem-focused coping factor was not considered for subsequent analyses. The improved models $C$ and $D$ are illustrated in Figure 1.

\section{Figure 1}

Structural model of the Brief-COPE
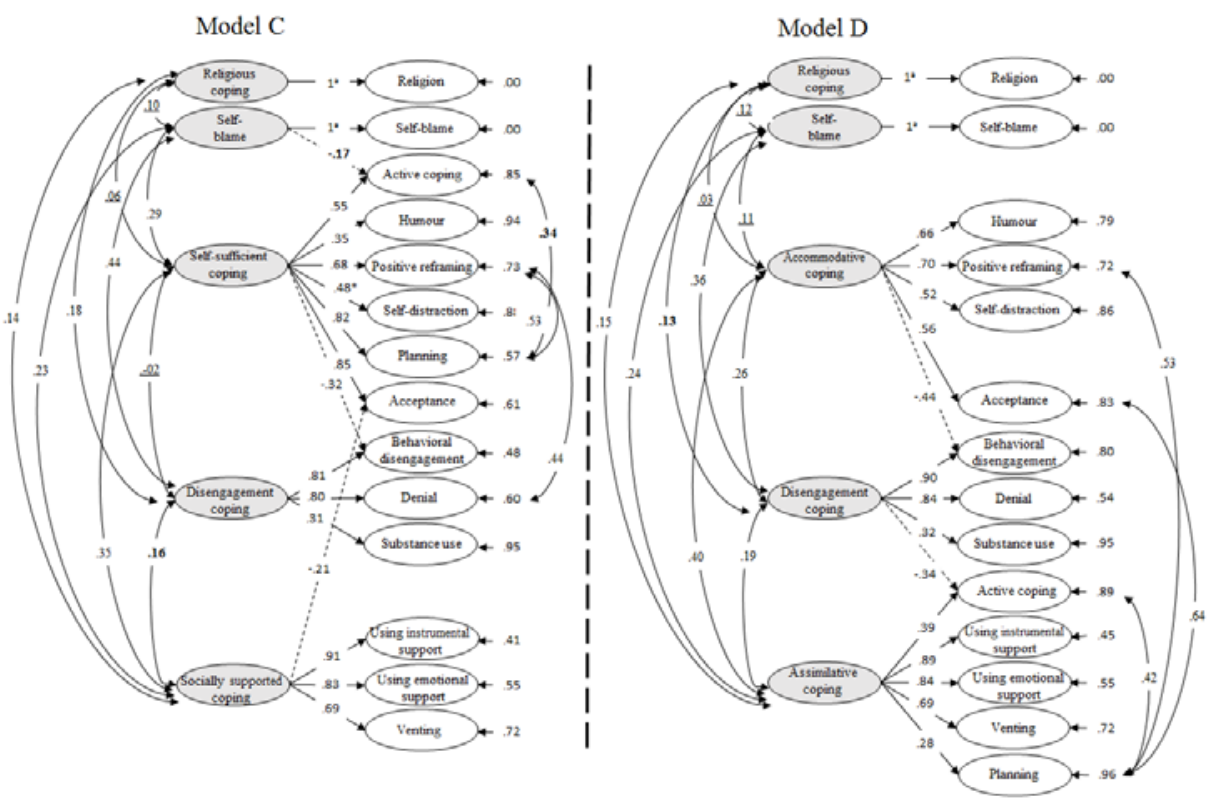

Notes: ${ }^{*} p \leq .05$; coefficients in plain text: $p \leq .01$; underline coefficients: $p>.05$. Cross-loadings (all $p \leq .01$ ) of item 1 on Active coping (model C: $\beta=.35$; model $D$ : $\beta=.38$ ); item 7 on Positive reframing $(\beta=.23$, $\beta=.27)$; item 19 on Denial $(\beta=.24, \beta=.20)$; item 20 on Denial $(\beta=-.33, \beta=-.42)$ and item 28 on Active coping $(\beta=-.30, \beta=-.20)$ and correlations between unique variance of item 9 and item 10 (model $C$ and model $D, r=.23, p \leq .01), 17-18(r=.25, r=.26$, both $p \leq .01)$ and 19-20 (both models, $r=-.13, p \leq .05$ ) are omitted for sake of simplicity. Dotted lines are cross-loadings on second factor order

\section{Convergent validity}

Pearson's correlations between the first and second order factors corresponding to structural models $C$ and $D$ and the criterion variables: subjective wellbeing and perceived stress are shown in Table 4. Disengagement coping obtained an opposite and significant relationship with wellbeing $(r=-.22, p \leq .001)$ and stress $(r=.34, p \leq .001)$. The same pattern of associations but with slightly higher values was observed in the self-blame subscale $(r=-.24, p \leq .001$ and $r=.36, p \leq .001$, respectively), while religious coping subscale was only weakly related to perceived stress $(r=.10, p \leq 0.05)$. 
Table 4

Convergent validity of the Brief-COPE second-order factors and component subscales

\begin{tabular}{|c|c|c|}
\hline Brief-COPE & Subjective wellbeing & Perceived stress \\
\hline \multicolumn{3}{|l|}{ Models C \& D components } \\
\hline Disengagement & $-.22 * \star \star$ & $.34 * \star \star$ \\
\hline 10. Denial & $-.15 * \star \star$ & $33^{* * *}$ \\
\hline 11. Substance use & $-.14 \star \star \star$ & $.10^{*}$ \\
\hline 12. Behavioural disengagement & $-.19 * \star \star$ & $.29 * \star \star$ \\
\hline Religion & -.05 & $.10^{*}$ \\
\hline Self-blame & $-.24^{* * *}$ & $.36^{* * *}$ \\
\hline \multicolumn{3}{|l|}{ Model C components } \\
\hline Self-sufficient & $.29 * \star *$ & $-.26 * * \star$ \\
\hline 1. Positive reframing & $.27 * * *$ & $-.19 * \star \star$ \\
\hline 2. Humor & $.13^{* \star \star}$ & $-.15 * * *$ \\
\hline 3. Acceptance & $.17 * * *$ & $-.20 * \star *$ \\
\hline 4. Self-distraction & $.08^{*}$ & -.01 \\
\hline 5. Active coping & $23 * * *$ & $-.22 * \star \star$ \\
\hline 6. Planning & $.13^{* *}$ & $-.11 * \star$ \\
\hline Socially supported & $.10^{*}$ & $.17 * \star \star$ \\
\hline 7. Instrumental support & $.12 * *$ & $.13^{* *}$ \\
\hline 8. Emotional support & $14 * * *$ & $.09 *$ \\
\hline 9. Venting & -.01 & $.19 * * *$ \\
\hline \multicolumn{3}{|l|}{ Model D components } \\
\hline Accommodative & $.26 * \star \star$ & $-.23 * \star \star$ \\
\hline 1. Positive reframing & $.27 * \star *$ & $-.19 * * *$ \\
\hline 2. Humor & $.13^{* * *}$ & $-.15 * * *$ \\
\hline 3. Acceptance & $.17 * \star \star$ & $-.20 * \star \star$ \\
\hline 4. Self-distraction & $.08^{\star}$ & -.01 \\
\hline Assimilative & $.17 * \star \star$ & .05 \\
\hline 5. Active coping & $.23^{* * *}$ & $-.22 * \star \star$ \\
\hline 6. Planning & $.13^{* *}$ & $-.11 \star \star$ \\
\hline 7. Instrumental support & $.12^{* *}$ & $.13^{* *}$ \\
\hline 8. Emotional support & $.14^{\star \star \star}$ & $.09^{*}$ \\
\hline 9. Venting & -.01 & $.19 * * \star$ \\
\hline
\end{tabular}

Note: ${ }^{*} p \leq .05 ;{ }^{* *} p \leq .01 ;{ }^{* * *} p \leq .001$.

Self-sufficient coping (model C) was positively associated with subjective wellbeing $(r=.29, p \leq .001)$ and negatively with perceived stress $(r=-.26, p \leq .001)$. Socially supported coping (model $C$ ) was also positively but weakly linked to both wellbeing $(r=.10, p \leq .05)$ and stress $(r=.17, p \leq .001)$. Assimilative coping (model D) was positively related to subjective wellbeing $(r \leq .17, p \leq .001)$ and it was not associated with stress; while accommodative coping (model D) was positively related to subjective wellbeing $(r \leq .26, p \leq .001)$ and negatively to stress $(r \leq-.23, p \leq .001)$. In order to deepen the convergent validity of each of the factors that compose both models and recognize the limitation implied by the low reliability of several of the original subscales, we also examine the association of these with the two criterion variables. The Disengagement subscales showed a pattern of relationships 
consistent with the factor. Likewise, the relationships between the subscales that comprise the different factors in model $C$ and the adjustment results were also consistent. However, as regards the model $D$, while the Accommodative coping factor and its subscales showed consistent relationships with subjective wellbeing and perceived stress, this pattern was only replicated in the case of Assimilative coping for its relationship with wellbeing. The subscales that compose this factor showed associations of different signs when the result variable contemplated was perceived stress.

\section{Discussion}

Brief-COPE is a widely used self-report for the assessment of coping in adult populations (e.g., Brasileiro et al., 2016; Datar, Shetty, \& Naphade, 2017) and also adolescents (e.g., García, Barraza-Peña, Wlodarczyk, Alvear-Carrasco, \& ReyesReyes, 2018; Lara, Bermúdez, \& Pérez-García, 2013). However, there is considerable variability in the 'ad hoc' structures of the Brief-COPE in the literature (e.g., Baumstarck et al., 2017; Doron et al., 2014; Mate et al., 2016). Consequently, the assessment of coping strategies through this instrument may be hard to synthesize into specific findings.

This study explored the possibility of a stable higher order structure for the Brief-COPE in a large sample of adolescents $(N=611)$ that facilitates the future comparison of results. Regarding the factorial structure, the models tested included the original 14-factor structure of the Brief-COPE proposed by Carver (1997) as well as three second-order models derived from the COPE results (Litman, 2006) and from Connor-Smith and Flachsbart proposal (2007). All models consider autodistraction as emotion-focused engagement coping and group the subscales of denial, substance use, and behavioural disengagement into a disengagement coping factor. Religion and self-blame were retained as independent subscales in both models by the complexity of the constructs themselves. Finally, models differ in grouping the subscales active coping, planning, auto-distraction, acceptance, positive reframing, humor, instrumental and emotional support, and venting. Two models arising from the COPE studies classify these subscales into one or two second-order factors depending on the grouping of the emotion- and the problemfocused coping in a single factor, while the model derived from the Connor-Smith and Flachsbart proposal (2007) groups them into two second-order factors: assimilative and accommodative coping. These hierarchical structures would also meet the requirements made in the coping literature regarding (i) not collecting simple functions or topological distinctions, since none distinction fully represents the structure of coping and (ii) not combining disparate strategies into overly broad dimensions (Compas et al., 2001; Coyne \& Gottlieb, 1996; Skinner et al., 2003).

Results of the CFA indicated that the best model was one defined by the original fourteen subscales. However, in line with other studies (e.g., Doron et al., 2014; García et al., 2018; Mate et al., 2016), the poor reliability of several subscales is an important reason not to use the standard Brief-COPE structure exclusively, but also consider alternative ways of grouping the items. The low reliability of some subscales may be due to the fact that the Spanish version used in the present study 
was developed in adult population (Morán et al., 2010). Nevertheless, the unsatisfactory internal consistency values have also been obtained in other studies with both, adolescents (e.g., Mate et al., 2016) and adults (Brasileiro et al., 2016; Doron et al., 2014; García et al., 2018). Another possible argument could be the reduced number of the items forming the subscales of the short version. This resulted in an assessment instrument that includes 14 subscales evaluated with only 2 items each, being probably a key cause of the Brief-COPE internal consistency problems (Emons, Sijtsma, \& Meijer, 2007; Little, Lindenberger, \& Nesselroade, 1999; Marsh, Hau, Balla, \& Grayson, 1998). As recommended, subscales must have a number of items equal to or greater than four (Fabrigar, Wegener, MacCallum, \& Strahan, 1999) to result in more robust dimensions. Consequently, it seems advisable to improve and/or include some items to increase the reliability of those often more problematic subscales. Based on our results, the use of active coping, planning, positive reframing, acceptance, venting, and self-distraction subscales in the adolescent population is not recommended.

Concerning the possible hierarchical structure of Brief-COPE, although the improved versions of the three tested models achieved a good fit, the proposal which divides coping as emotion- or problem-focused in two different factors should also be questioned because of the low reliability value obtained by this last factor. The other two structures reached acceptable reliability indices in all factors initially supporting their consideration in future work to regroup the subscales of the BriefCOPE into higher-order categories. Both structures favour the use of all subscales/items of the instrument and facilitate the data interpretation by handling not only more stable categories, but specially incorporating the most widely distinctions used to describe the coping structure (Carver \& Connor-Smith, 2010).

The study also examined the convergent validity of the factors and its corresponding subscales Brief-COPE C and D hierarchical structures in terms of its association with measures of perceived stress and subjective wellbeing. Unlike the other factors, the subscales conforming Assimilative coping showed positive and negative associations with perceived stress, which could explain the absence of relationship between the factor and the criterion. The disparate performance of the strategies forming Assimilative coping limits its usefulness like a category and underlines the need for future studies (exploring, for example, its association with different adjustment criteria) before the hierarchical structure that includes it (model D) could be recommended as a possible grouping of the COPE-Brief subscales.

The association between the only model that successfully met the different criteria examined (model C) and the adjustment variables highlights the functional nature of the Self-sufficient coping as opposed to the Self-blame and Disengagement coping. Thus, congruent with literature (Moskowitz, Hult, Bussolari, \& Acree, 2009; Sirois \& Kitner, 2015), our outcomes support the idea that dealing with stressor, either by trying to control itself or by trying to adapt to it would be adaptive, while attempting to escape feelings of distress and blame oneself are shown as maladaptive strategies.

More inconsistent was the pattern of relationships shown by Socially supported and Religious coping. Socially supported coping showed a weak positive association with both perceived stress and wellbeing. Two reasons could explain the positive 
association with both criterion variables. The perception that others can and will provide necessary resources may redefine the potential for harm posed by a situation and/or bolster one's perceived ability to cope with imposed demands. However, the uncertainty perceived by the person about whom to contact and whether will actually receive the expected support may itself constitute a source of stress. This fact could be especially relevant in a period such as adolescence when individuals are starting to sharpen close relationships with peers (Gray, Culpepper, \& Welsh, 2012): there is an increase in the amount of time spent with them, a greater orientation toward peer acceptance and conformity, an increased importance of close friendships, and the emergence of romantic relationships (La Greca \& Harrison, 2005). The positive but weak relationship between religious coping and perceived stress outlines this strategy as maladaptive. However, we have already mentioned the criticisms for using one-dimensional religious coping measures (Lavery \& O'Hea, 2010) such as the one included in the Brief-COPE, since they may obscure the distinctive contribution that religion makes to the coping process (Pargament, 2011). In fact, research results have shown the existence of different religious coping strategies which are grouped into two overarching forms of religious coping, positive and negative, associated in the opposite direction with different adjustment outcomes (Ano \& Vasconcelles, 2005; Bjorck, Braese, Tadie, \& Gililland, 2010; Pargament, 2011). The superficial approach of the two items assessing religious coping at Brief-COPE ('I have been trying to find comfort in my religion or spiritual belief' and 'I have been praying or meditating') precludes any parallelism with specific religious coping strategies and thus hinders the interpretation of this subscale.

In brief, our results constitute a significant step forward in the improvement of the usefulness and comparability of the coping results obtained with an instrument as widely used as the Brief-COPE. The way subjects deal with stressful transactions is key to their wellbeing. Particularly, the knowledge of how adolescents deal with, or respond to, stressors associated with the substantial changes experienced in this developmental period (Markova \& Nikitskaya, 2017) is a necessary item of information to advance in the direction of promoting the adolescent's health recently claimed by the World Health Organization (WHO, 2017). In addition, our findings support the use of a valid way of grouping the Brief-COPE subscales, in which Religious and Self-blame constitute independent subscales and the remaining subscales are grouped into three factors: Self-sufficient, Socially supported, and Disengagement coping. This hierarchical model is not only based on a large tradition of studies about coping distinctions and groupings, but it corresponds closely to the model emphasized by research on the adolescent population (Frydenberg, 1997; Frydenberg \& Lewis, 1997; Seiffge-Krenke, 2009). In addition, this Brief-COPE structure: i) makes the use of this instrument profitable, without the need to resort to ad hoc structures and ii) allows for more detailed information on specific coping strategies, insofar as its use does not prevent the exploration of subscales with appropriate reliability levels.

However, some limitations in our study should be also noted. The sample only included Spanish adolescents of Valencia Community, aged 14 to 18 years, limiting the generalizability of findings. Future research could be carried out in population 
groups with other age ranges (e.g., adults) to confirm the general validity of the substantiated higher-order coping structure. The cross-sectional design does not allow statements on nature or type of relationships between the coping styles, perceived stress and subjective wellbeing. Further longitudinal studies that use a sequential temporal evaluation of the variables should be performed in order to demonstrate a causal relation between analyzed variables. Finally, an additional limitation was the exclusive use of self-reports measures, although gathering information directly from participants is convenient and feasible method of data collection. Future research could gather information from additional reporters in order to strengthen the results obtained.

\section{References}

Ano, G. A., \& Vasconcelles, E. B. (2005). Religious coping and psychological adjustment to stress: A meta-analysis. Journal of Clinical Psychology, 61(4), 1-20. doi: $10.1002 / j c l p .20049$

Aliaga F., \& Capafons, A. (1996). La medida del afrontamiento: Revisión crítica de la "escala de modos de coping" (Ways of Coping) [Coping measure: A critical review of the Ways of Coping scale]. Ansiedad y Estrés, 2(1), 17-26.

Ayers, T. S., Sandler, I. N., West, S. G., \& Roosa, M. W. (1996). A dispositional and situational assessment of children's coping: Testing alternative models of coping. Journal of Personality, 64(4), 923-958. doi: 10.1111/j.1467-6494.1996.tb00949.x

Baumstarck, K. Alessandrini, M., Hamidou, Z., Auquier, P., Leroy, T., \& Boyer, L. (2017). Assessment of coping: A new French four-factor structure of the Brief-COPE inventory. Health and Quality of Life Outcomes, 15(1),8. doi: 10.1186/s12955-016-0581-9

Bentler, P. M. (2006). EQS structural equations program manual. Encino, CA: Multivariate Software.

Bjorck, J. P., Braese, R. W., Tadie, J. T., \& Gililland, D. D. (2010). The Adolescent Religious Coping scale: Development, validation, and cross-validation. Journal of Child and Family Studies, 19(3), 343-359. doi: 10.1007/s10826-009-9305-7

Brasileiro, S. V., Orsini, M. R., Cavalcante, J. A., Bartholomeu, D., Montiel, J. M., Costa, P. S. S., \& Costa, L. R. (2016). Controversies regarding the psychometric properties of the Brief-COPE: The case of the Brazilian-Portuguese version "COPE Breve". Plos One, 11(3)، e0152233.

Carver, C. S. (1997). You want to measure coping but your protocol's too long: Consider the Brief-COPE. International Journal of Behavioral Medicine, 4(1), 92-100. doi: 10.1207/s15327558ijbm0401_6

Carver, C. S., \& Connor-Smith, J. (2010). Personality and coping. Annual Review of Psychology, 61, 679 -704. doi: 10.1146/annurev.psych.093008.100352

Carver, C. S., Scheier, M. F., \& Weintraub, J. K. (1989). Assessing coping strategies: A theoretically based approach. Journal of Personality and Social Psychology, 56(2), 267283. doi: 10.1037/0022-3514.56.2.267

Cassaretto, M., \& Pérez-Araníbar, C. (2016). Stress coping: Adaptation of the questionnaire COPE in university's students of Lima. Revista Iberoamericana de Diagnóstico y Evaluación -e Avaliação Psicológica, 42(2), 95-109. doi: 10.21865/RIDEP42-95

Cohen, S., Kamarck, T., \& Mermelstein, R. (1983). A global measure of perceived stress. Journal of Health and Social Behavior, 24(4), 385-396. doi: 10.2307/2136404

Compas, B. E., Connor-Smith, J. K., Saltzman, H., Thomsen, A. H., \& Wadsworth, M. E. (2001). Coping with stress during childhood and adolescence: Problems, progress, and potential in theory and research. Psychological Bulletin, 127, 87-127. doi:10.1037/0033-2909.127.1.87 
Connor-Smith, J. K., Compas, B. E., Wadsworth, M. E., Thomsen, A. H., \& Saltzman, H. (2000). Responses to stress in adolescence: Measurement of coping and involuntary stress responses. Journal of Consulting and Clinical Psychology, 68(6), 976-992. doi: 10.1037/0022-006X.68.6.976

Connor-Smith, J. K., \& Flachsbart, C. (2007). Relations between personality and coping: A meta-analysis. Journal of Personality and Social Psychology, 93(6), 1080-1107. doi: 10.1037/0022-3514.93.6.1080

Coyne, J. C., \& Gottlieb, B. H. (1996). The mismeasure of coping by checklist. Journal of Personality, 64(4), 959-991. doi: 10.1111/j.1467-6494.1996.tb00950.x

Crasovan, D. I., \& Sava, F. A. (2013). Translation, adaptation, and validation on Romanian population of COPE questionnaire for coping mechanisms analysis. Cognition, Brain, Behavior. An Intedisciplinary Journal, 17(1), 61-76.

Crespo, M., \& Cruzado, J. A. (1997). La evaluación del afrontamiento: Adaptación española del cuestionario COPE con una muestra de estudiantes universitarios [Coping assessment: Spanish adaptation of the COPE questionnaire with a sample of university students]. Análisis y Modificación de Conducta, 23(92), 797-830.

Datar, M. C., Shetty, J. V., \& Naphade, N. M. (2017). Stress and coping styles in postgraduate medical students: A medical college-based study. Indian Journal of Social Psychiatry, 33(4), 370-374. doi: 10.4103/ijsp.ijsp_59_16

Doron, J., Stephan, Y., Boiché, J., \& Le Scanff, C. (2009). Coping with examinations: Exploring relationships between students' coping strategies, implicit theories of ability, and perceived control. British Journal of Educational Psychology, 79(3), 515-528. doi: 10.1348/978185409X402580

Doron, J., Trouillet, R., Gana, K., Boiché, J., Neveu, D., \& Ninot, G. (2014). Examination of the hierarchical structure of the Brief-COPE in a French sample: Empirical and theoretical convergences. Journal of Personality Assessment, 96(5), 567-575. doi: 10.1080/00223891.2014.886255

Emons, W. H. M., Sijtsma, K., \& Meijer, R. R. (2007). On the consistency of individual classification using short scales. Psychological Methods, 12(1), 105-120. doi:10.1037/1082-989X.12.1.105

Extremera, N., Fernández-Berrocal, P., González-Herrero, V., \& Cabello, R. (2009). Una validación preliminar de la versión española de la Subjective Happiness Scale [A preliminary validation of the Spanish version of the Subjective Happiness Scale]. In P. Fernández- Berrocal (Ed.), Avances en el estudio de la inteligencia emocional (pp. 3944). Santander: Fundación Marcelino Botín.

Fabrigar, L. R., Wegener, D. T., MacCallum, R. C., \& Strahan, E. J. (1999). Evaluating the use of exploratory factor analysis in psychological research. Psychological Methods, 4, 272299. doi: 10.1037/1082-989X.4.3.272

Folkman, S., \& Lazarus, R. S. (1980). An analysis of coping in a middle-aged community sample. Journal of Health and Social Behavior, 21(3), 219-239. doi: 10.2307/2136617

Folkman, S., \& Lazarus, R. S. (1985). If it changes it must be a process: Study of emotion and coping during three stages of a college examination. Journal of Personality and Social Psychology, 48(1), 150-170. doi: 10.1037/0022-3514.48.1.150

Frydenberg, E. (1997). Adolescent coping: Theoretical and research perspectives. London: Routledge.

Frydenberg, E., \& Lewis, R. (1997). Manual: Escalas de afrontamiento para adolescentes (ACS) [Adolescent Coping Scale, ACS: Manual]. Madrid: TEA.

García, F. E., Barraza-Peña, C. G., Wlodarczyk, A., Alvear-Carrasco, M., \& Reyes-Reyes, A. (2018). Psychometric properties of the Brief-COPE for the evaluation of coping strategies in the Chilean population. Psicologia: Reflexão e Crítica, 31, 22. doi: 10.1186/s41155018-0102-3

Gray, S., Culpepper, C., \& Welsh, D. (2012). Adolescence. In V. Ramachandran (Ed.), Encyclopedia of human behavior (2 ${ }^{\text {nd }}$ ed.) (pp. 22-29). Oxford: Elsevier. 
Hair, J. F., Anderson, R. E., Tatham R. L., \& Black, W. C. (1999). Multivariate data analysis. Upper Saddle River, NJ: Prentice-Hall International.

Jackson, D. L., Gillaspy, J. A., \& Purc-Stephenson, R. (2009). Reporting practices in confirmatory factor analysis: An overview and some recommendations. Psychological Methods, 14(1), 6-23. doi: 10.1037/a0014694

Janoff-Bulman, R. (1979). Characterological versus behavioral self-blame: Inquiries into depression and rape. Journal of Personality and Social Psychology, 37(10), $1798-1809$. doi: 10.1037//0022-3514.37.10.1798

Kallasmaa, T., \& Pulver, A. (2000). The structure and properties of the Estonian COPE inventory. Personality and Individual Differences, 29(5), 881-894. doi: 10.1016/S01918869(99)00240-8

Kristiansen, E., Roberts, G. C., \& Abrahamsen, F. E. (2008). Achievement involvement and stress coping in elite wrestling. Scandinavian Journal of Medicine \& Science in Sports, 18(4), 526-538. doi: 10.1111/j.1600-0838.2007.00646.x

La Greca, A. M., \& Harrison, H. M. (2005). Adolescent peer relations, friendships, and romantic relationships: Do they predict social anxiety and depression? Journal of Clinical Child and Adolescent Psychology, 34(1), 49-61. doi: 10.1207/s15374424jccp3401_5

Lara, M. D., Bermúdez, J., \& Pérez-García, A. M. (2013). Positividad, estilo de afrontamiento y consumo de tabaco y alcohol en la adolescencia [Positivity, coping style and tobacco and alcohol use in adolescence]. Electronic Journal of Research in Educational Psychology, 11(2), 345-366. doi: 10.14204/ejrep.30.13036

Lavery, M. E., \& O'Hea, E. L. (2010). Religious/spiritual coping and adjustment in individuals with cancer: Unanswered questions, important trends, and future directions. Mental Health, Religion \& Culture, 13(1), 55-65. doi: 10.1080/13674670903131850

Lazarus, R. S., \& Folkman, S. (1984). Stress, appraisal, and coping. New York, NY: Springer.

Litman, J. A. (2006). The COPE inventory: Dimensionality and relationships with approachand avoidance-motives and positive and negative traits. Personality and Individual Differences, 41(2), 273-284. doi: 10.1016/j.paid.2005.11.032

Little, T. D., Lindenberger, U., \& Nesselroade, J. R. (1999). On selecting indicators for multivariate measurement and modeling with latent variables: When "good" indicators are bad and "bad" indicators are good. Psychological Methods, 4(2), 192-211.

Lyne, K., \& Roger, D. (2000). A psychometric re-assessment of the COPE questionnaire. Personality and Individual Differences, 29(2), 321-335. doi: 10.1016/S01918869(99)00196-8

Lyubomirsky, S., \& Lepper, H. (1999). A measure of subjective happiness: Preliminary reliability and construct validation. Social Indicators Research, 46(2), 137-155. doi: 10.1023/A:1006824100041

Markova, S., \& Nikitskaya, E. (2017). Coping strategies of adolescents with deviant behaviour. International Journal of Adolescence and Youth, 22(1), 36-46. doi: 10.1080/02673843.2013.868363

Marsh, H. W., Hau, K. T., Balla, J. R., \& Grayson, D. (1998). Is more ever too much? The number of indicators per factor in confirmatory factor analysis. Multivariate Behavioral Research, 33(2), 181-220. doi:10.1207/s15327906mbr3302_1

Mate, A. I., Andreu, J. M., \& Peña, M. E. (2016). Propiedades psicométricas del "Inventario breve de afrontamiento" (COPE-28) en una muestra de adolescentes [Psychometric properties of the Spanish version of the Brief-COPE Inventory (COPE-28) in a sample of teenagers]. Behavioral Psychology/Psicología Conductual, 24(2), 305-318.

Mohanraj, R., Jeyaseelan, V., Kumar, S., Mani, T., Rao, D., Murray, K. R., \& Manhart, L. E. (2015). Cultural adaptation of the Brief-COPE for persons living with HIV/AIDS in southern India. AIDS and Behavior, 19(2), 341-351. doi: 10.1007/s10461-014-0872-2

Morán, C., Landero, R., \& González, M. T. (2010). COPE-28: Un análisis psicométrico de la versión en español del Brief-COPE [COPE-28: A psychometric analysis of the Spanish version of the Brief-COPE]. Universitas Psychologica, 9(2), 543-552. 
Muller, L., \& Spitz, E. (2003). Multidimensional assessment of coping: Validation of the BriefCOPE among French population. Encephale, 29(6), 507-518. doi: ENC-12-2003-29-60013-7006-101019-ART5

Moskowitz, J. T., Hult, J. R., Bussolari, C., \& Acree, M. (2009). What works in coping with HIV? A meta-analysis with implications for coping with serious illness. Psychological Bulletin, 135(1), 121-141. doi: 10.1037/a0014210.

Pargament, K. I. (2011). Religion and coping: The current state of knowledge. In S. Folkman (Ed.), The Oxford handbook of stress, health, and coping (pp. 269-288). Oxford: Oxford University Press.

Remor, E., \& Carrobles, J. A. (2001). Versión española de la Escala de estrés percibido (PSS14): Estudio psicométrico en una muestra $\mathrm{VIH}+$ [Spanish version of the Perceived Stress Scale (PSS-14): Psychometric study in a HIV+ sample]. Ansiedad y Estrés, 7(2-3), 195201.

Schottenbauer, M. A., Klimes-Dougan, B., Rodriguez, B. F., Arnkoff, D. B., Glass, C. R., \& LaSalle, V. H. (2006). Attachment and affective resolution following a stressful event: General and religious coping as possible mediators. Mental Health, Religion and Culture, 9(5), 448-471. doi: 10.1080/13694670500440684

Seiffge-Krenke, I. (2009). Coping with relationships stressors: A decade review. Journal of Research on Adolescence, 1, 196-210. doi:10.1111/j.1532-7795.2010.00723.x

Sica, C., Novara, C., Dorz, S., \& Sanavio, E. (1997). Coping strategies: Evidence for crosscultural differences? A preliminary study with the Italian version of Coping Orientations to Problems Experienced (COPE). Personality and Individual Differences, 23(6), 10251029. doi: 10.1016/S0191-8869(97)00112-8

Sirois, F. M., \& Kitner, R. (2015). Less adaptive or more maladaptive? A meta-analytic investigation of procrastination and coping. European Journal of Personality, 29(4), 433444. doi: 10.1002/per.1985

Skinner, E. A., Edge, K., Altman, J., \& Sherwood, H. (2003). Searching for the structure of coping: A review and critique of category systems for classifying ways of coping. Psychological Bulletin, 129(2), 216-269. doi: 10.1037/0033-2909.129.2.216

Walker, L. S., Smith, C. A., Garber, J., \& Van Slyke, D. A. (1997). Development and validation of the Pain Response Inventory for children. Psychological Assessment, 9(4), 392-405. doi: 10.1037/1040-3590.9.4.392

World Health Organization. (2017). Global accelerated action for the health of adolescents (AA-HA!): Guidance to support country implementation. Geneva: Switzerland.

RECEIVED: March 30, 2020

ACCEPTED: November 21, 2020 


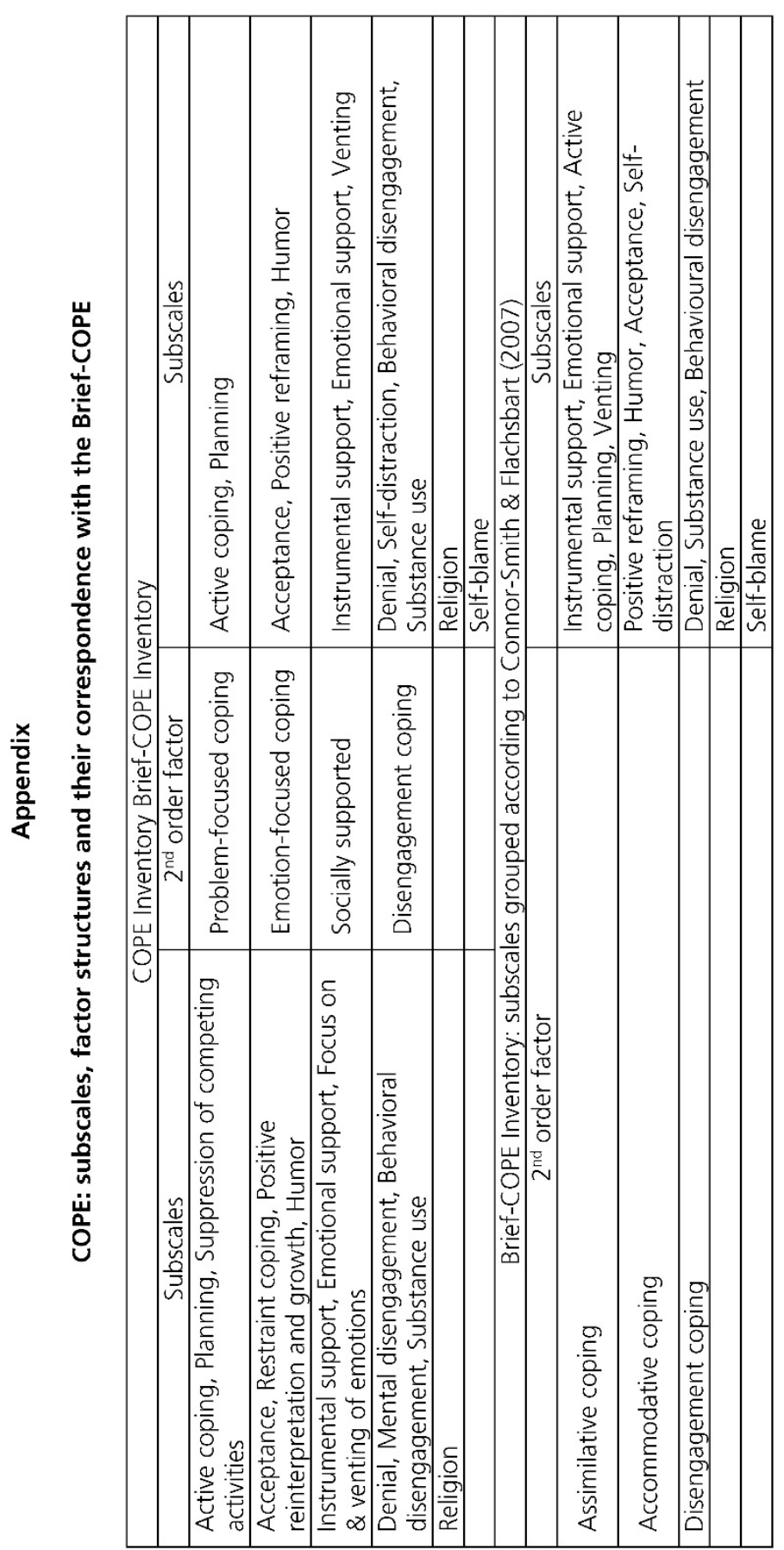

